\title{
電極表面反応における振動現象と時空間パターン形成
}

\author{
中 西 周 次 \\ 大阪大学大学院基礎工学研究科物質創成専攻 遥 560-8531 大阪府豊中市待兼山町 1-3 \\ 科学技術振興機構・さきがけ 䧟 560-8531 大阪府豊中市待兼山町 1-3
}

(2007 年 7 月 9 日受理)

\section{Spatiotemporal Reaction Patterns at Electrode Surfaces}

\author{
Shuji NAKANISHI \\ Division of Chemistry, Graduate School of Engineering Science, Osaka University \\ 1-3 Machikaneyama, Toyonaka, Osaka 560-8531 \\ PRESTO, Japan Science, and Technology Agency \\ 1-3 Machikaneyama, Toyonaka, Osaka 560-8531
}

(Received July 9, 2007)

\begin{abstract}
Formations of spatiotemporal patterns in nonlinear chemical reactions have attracted a lot of attentions from the viewpoint of dynamic self-organization in molecular systems. It is now widely known that such spatiotemporal patterns can also be observed in electrochemical systems. The electrochemical system has advantages for the study of the dynamic spatiotemporal patterns : (1) the distance from the equilibrium can be tuned continuously and reversibly by simply changing the electrode potential, (2) the diffusion processes can be flexibly controlled by tuning the structure of the electrochemical cell, and (3) the mode of the spatiotemporal patterns can be tuned easily by changing the geometrical arrangements of the electrodes and the applied potential or current. Here we review experimental and theoretical studies on the spatiotemporal patterns formed at electrode surfaces, by taking electrochemical oscillation during $\mathrm{H}_{2} \mathrm{O}_{2}$ reduction on Pt electrode as a representative example.
\end{abstract}

KEYWORDS : spatiotemporal pattern, oscillation, electrochemistry, nonlinear phenomena, self-organization

\section{1.は じめに}

正のフィードバック機構（自己触媒機構）を持つ化学 反応と拡散とが共役すると, その反応が巨視的な動的パ ターンを形成する場合があることは今ではよく知られて いる。表面科学の分野では, 単結晶貴金属表面上での $\mathrm{CO}$ 酸化反応で見られるスパイラル状のパターン形成 ${ }^{1)}$ が大変有名である。一般に, この種の動的パターンは以 下の反応拡散（Reaction-Diffusion (RD)) 方程式で記述 することができる。

$$
\begin{aligned}
& \frac{\delta u}{\delta t}=f(u, v)+D_{\mathrm{u}} \nabla^{2} u \\
& \frac{\delta v}{\delta t}=g(u, v)+D_{\mathrm{v}} \nabla^{2} v
\end{aligned}
$$

E-mail : shuji@chem.es.osaka-u.ac.jp
ここで第 1 項が反応項, 第 2 項が拡散項であり, 反応 ダイナミクス（関数 $f, g)$ や拡散係数 $\left(D_{\mathrm{u}}, D_{\mathrm{v}}\right)$ の大き さとその相対比などに応じて得られるパターンの時間 的, 空間的挙動が変化する。

電気化学反応系はこうした反応拡散パターンの宝庫で ある。実際, 電極触媒反応, 酸化溶解反応, 還元析出反 応と全ての型の反応で振動やパターン形成などの動的秩 序の発現が報告されている ${ }^{2,3)}$ 。またその歴史も大変古 く, 最初の報告は 19 世紀にまで遡る。このことは, 他 の反応系での時空間秩序の発現例が上述した真空中での CO 酸化反応や均一系における Belousov-Zhabotinsky 反 応など数例しかないことを考えると，驚くべき事実であ る。これに加えて, 電気化学反応系では, 系の重要な分 岐パラメーターである “平衡からの距離” が電極電位の 制御により連続的, 可逆的, そして瞬間的にチューニン 
グできる。このように, 電気化学系は反応拡散パターン の本質を探るのに格好の系であると言える。筆者らは電 気化学系のこれらの特徴に着目し研究を進めてきた。本 稿では, 電極表面上での反応拡散パターン発現に対する 実験的および数理的研究に関する筆者らの最近の研究成 果を紹介する。

\section{2. 電気化学振動現象}

筆者らは，これまで酸性水溶液中における $\mathrm{Pt}$ 電極上 での $\mathrm{H}_{2} \mathrm{O}_{2}$ 還元反応で観測される電気化学振動現象を中 心に研究を進めてきた。これは非常に簡単な反応であり ながら, 少しの条件の変化で多くの種類（総計 7 種類） の電気化学振動が現れる。これらは全て筆者らが発見し たもので, その発見の順番に振動 $\mathrm{A}, \mathrm{B}, \mathrm{C} \cdots$ と名付け ている。この事実からも電気化学系では振動現象が現れ やすいことが良くわかる。では, なぜ電気化学反応系で はこのように振動現象が現れやすいのだろうか。ここで は最もシンプルな振動 $\mathrm{A}^{4)}$ を例として取り上げ, その理 由を考えてみる。

Fig. 1 （a）に電位規制下で得られた電流密度 $(j)$-電
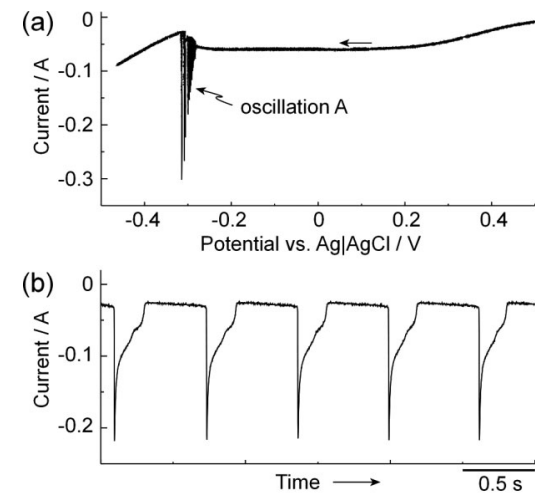

(c)

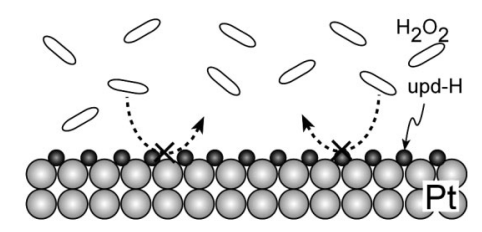

(d)

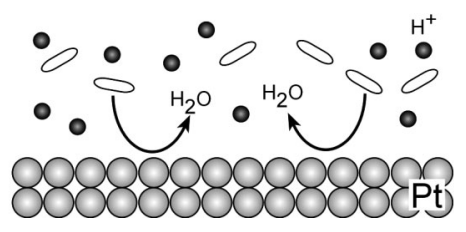

Fig. 1. (a) Potential-regulated current $(i)$ vs. potential $(U)$ obtained at a scan rate of $10 \mathrm{mV} / \mathrm{s}$. (b) $i$ vs. time $(t)$ at $U=-0.30 \mathrm{~V}$. Electrolyte : $0.3 \mathrm{M} \mathrm{H}_{2} \mathrm{O}_{2}+0.5 \mathrm{M}$ $\mathrm{H}_{2} \mathrm{SO}_{4}$. (c) and (d) Schematic representations of surface reactions in the low-and high-current states, respectively.
位（U) 曲線を示す。レストポテンシャル（約 $+0.5 \mathrm{~V}$ vs. $\mathrm{Ag} \mid \mathrm{AgCl}$ ) から電位を負の方向へ掃引していくと, $\mathrm{H}_{2} \mathrm{O}_{2}$ の還元電流が流れ始め, それはやがて約 $0.3 \mathrm{~V}$ 付 近で拡散律速となる。そして電位が Pt 電極表面上に upd-H 型*の水素が吸着する領域に入ると, 負性微分抵 抗**が現れ，ここで電流が自発的に振動を始める。この 負性微分抵抗領域で電位を一定に保持すると Fig. 1（b)

(a)

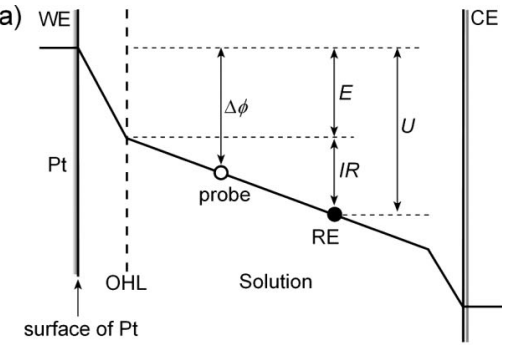

(b)

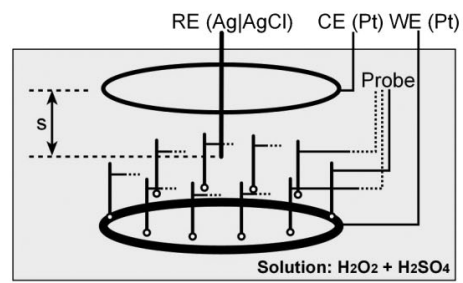

(c)

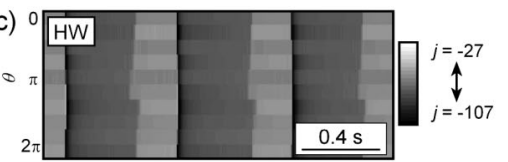

(d) 00
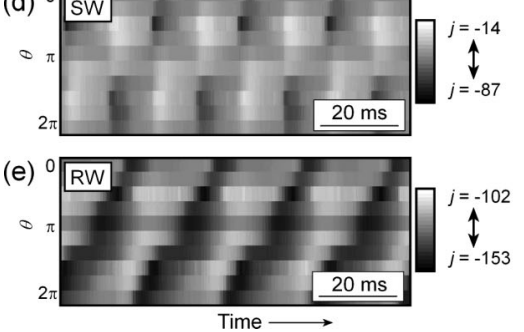

Fig. 2. Schematic illustrations of (a) potential profile in the region between the electrode $(\mathrm{Pt})$ surface and the counter electrode and (b) the electrode arrangement in a cylindrical cell, WE : the working electrode, $\mathrm{CE}$ : the counter electrode, and Probe: the probe electrodes. (c) -(e) Observed spatiotemporal waves (c) at $U=-0.33 \mathrm{~V}$ with the RE placed close to the CE, (d) at $U=-0.25 \mathrm{~V}$ and (e) $U=-0.30 \mathrm{~V}$ with the RE placed close to the WE. The local current density is calculated under the assumption that the observed potential of the $\mathrm{PE}$ is in proportion to the local current density near the PE.

upd-H とは under-potential deposited hydrogen の略で, Pt 電極において水素発生電位より約 $0.3 \mathrm{~V}$ ほど正の電位 から生成する安定な吸着水素をさす。

**負性微分抵抗領域とは過電圧を上げているにもかかわ らず電流值が減少する領域のことをさす。 
に示す波形の電流振動が得られる。この波形を追って電 流振動のメカニズムを説明しよう。

低電流状態では, Fig. 1 (c) に模式的に示すように, upd-H が Pt 電極表面に生成し，これが $\mathrm{H}_{2} \mathrm{O}_{2}$ 還元反応を 阻害するため電流があまり流れない。この状態に至る前 段階で $\mathrm{H}_{2} \mathrm{O}_{2}$ の電極表面濃度はほぼ゙ロになっている が, それは拡散によって時間とともに増え, これに伴っ て電流が少しずつ増加する。いま, 印加電位 $U$ は外部 装置（ポテンショスタット）により一定に固定されてい る。したがって, 還元電流 (負の電流) が流れると, Helmholtz 二重層にかかる真の電極電位 $(E)$ は溶液中 でのオーミック $(I R)$ ドロップの分だけ $U=E+I R$ の関 係（Fig. 2 (a)）に基づき正にシフトする。還元電流の 増加による $E$ の正へのシフトは upd-H 被覆率の減少, すなわち $\mathrm{H}_{2} \mathrm{O}_{2}$ 還元反応サイトの増加を導き, これによ りさらに電流が増加する。このように, 電流の増加 $\rightarrow I R$ ドロップの増加 $\rightarrow E$ の正シフト $\rightarrow$ upd-H 被覆率の減少 $\rightarrow$ 電流の増加という正のフィードバック機構が働き, 電流 が急激に増大して, 系は高電流状態 (Fig. 1 (d) ) へと 達する。

高電流状態では, upd-H は Pt 表面から脱離しており, 効率よく $\mathrm{H}_{2} \mathrm{O}_{2}$ 還元が起こる。そのため, $\mathrm{H}_{2} \mathrm{O}_{2}$ 表面濃 度は減少し, その結果として電流も減少する。このと き, 電流の減少 $\rightarrow I R$ ドロップの減少 $\rightarrow E$ の負シフト $\rightarrow$ upd-H 被覆率の増大 $\rightarrow$ 電流の減少という先ほどとは逆向 きの正のフィードバック機構が働き, 電流が急激に減少 して, 系は低電流状態へと戻る。これらの過程が繰り返 されることにより電流が自発的に振動する。

以上からわかるように, 電気化学振動の発現には(1)負 性微分抵抗と (2)溶液中の $I R$ ドロップの存在がキーとな っている。負性微分抵抗は upd-H のような反応阻害種 の増加や, 反応促進種の減少などに起因して電気化学系 では頻繁に現れる。また $I R$ ドロップは程度に差はある ものの常に溶液中に存在する。このように, 上記の条件 は容易に達成されるため, 電気化学系では振動現象や時 空間パターン形成が頻繁に現れることになる。電気化学 振動には他にも電流規制下で現れるものなどがあるが, いずれも電気的作用がその発現機構に深く関与してい る。これに関しては Strasser らによる先駆的な研究 ${ }^{5)}$ あるので，詳細はそちらを参照されたい。

\section{3. 電極表面上での時空間反応パターン形成}

電気化学振動下における電極表面上での時空間反応パ ターン形成は 1988 年にニッケルの酸化溶解反応系で初

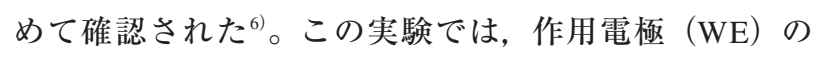
すぐ近くに溶液電位をプローブするための電極（プロー

ブ電極，PE）を配置し，WE-PE 間の電位差（ $\Delta \phi ）$ を測 定する（Fig. 2 (a)）。系に電流が流れると IR ドロップ 分だけ溶液電位が変化するので, $\Delta \phi$ は PEが置かれた 付近の局所的な電流を測定していることになる。こうし たPE を複数本, WE に沿って配置することで, 電流の 空間分布，すなわち時空間反応パターンが測定できる。

この方法に習い, 筆者らも振動 A の条件下に打いて $\mathrm{Pt}$ 電極表面上に形成される時空間パターンを観測した。 ここでは, 後で示す数理的考察を可能とするために, Pt 電極の形状をリング状として系に周期境界条件を与えて いる (Fig. 2（b））。このとき得られた時空間パターンは 設定電位 $(U)$ と電極の幾何学的配置に依存して変化す る。参照電極（RE）をWEから遠ざけて対極 (CE) の 近くに配置した場合には, 電位によらず空間的に一様な 振動パターン (Fig. 2 (c), 以後これを Homogeneous Wave（HW）と呼ぶ）が得られる。一方，REをWEに 近づけて配置した場合には, 反応位相の空間対称性が破 られる。このとき, 振動発現電位のほぼ正端の狭い電位 領域ではPtリング状を 2 分し互いに逆位相で反応が振 動するパターン（Fig. 2 (d), Standing Wave (SW) ) が, 電位を少し負にすると Pt リング状を反応活性部が回転 するパターン (Fig. 2 (e), Rotating Wave (RW)) が観 測される。電位がさらに大きく負の電位領域では, 初期 状態に強く依存する乱雑なパターンが現れる。

一般に, 電気化学系に扔けるパターン形成は Positive Local Coupling (PLC, Fig. 3 (a)) と Negative Global Coupling（NGC, Fig. 3 (b) ) という二種の相反する空 間カップリング効果が競合する結果（Fig. 3 (c)）とし て得られる ${ }^{3,7)}$ 。PLC はWE 上の異なる二点間における 電解質溶液中の IR ドロップを介した電気的な相互作用 によるカップリングである。互いに近接する二点のう ち, 一方の点で電流密度が高くなると, それに伴い近傍 での溶液中の電流線が変化し，これによって電位が変化

(a)

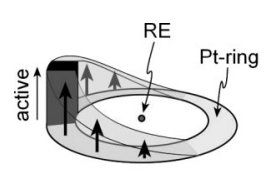

PLC

(c)

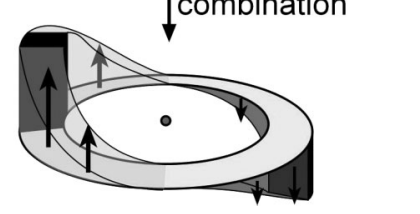

Fig. 3. Schematic illustrations for explaining the PLC and the NGC effects and their combination. 
する。この電位変化が他点に影響し，そこでの真の電極 電位を同位相で変化させる。このように, PLC は空間 的に均一なパターン形成に寄与し, HW を導く。一方, RE が WEに近い場合には, 局所的な電流増加により REの置かれた位置での溶液電位が CE に比べて大きく 負にシフトする。WE-RE 間の電位が外部装置により一 定に制御されているので, RE 位置での電位の負方向へ のシフトは活性部の電極電位を大きく負へシフトさせ電 流密度を減少させる。これが NGC 効果であり, 空間的 に非一様なパターン形成に寄与し, SW や RW を導く。 PLC 効果は距離に強く依存して (Localに) 働くのに対 し, NGC 効果は距離に依存せず電極全体に等価に (Global に) 働く。

\section{4. 数理的アプローチ}

次に，上に示した様々な時空間パターンの発現が数理 的にどう理解できるのかを考えよう。Fig. 4 (a) に電気 化学系の等価回路を示す。まずは REが CE と同じ面に 置かれた場合 $(s=0)$ を考えてみる。このとき, 電極表 面上のある一点における電極電位 $E$ 打よび表面 $\mathrm{H}_{2} \mathrm{O}_{2}$ 濃 度 $C$ に関して以下の微分方程式を得ることができる。

$$
A C_{\mathrm{DL}} \frac{d E}{d t}+I_{\mathrm{F}}(E, C, \theta)=\frac{U-E}{R_{\Omega}}
$$

(a)

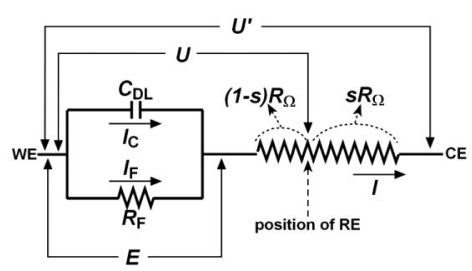

(b)

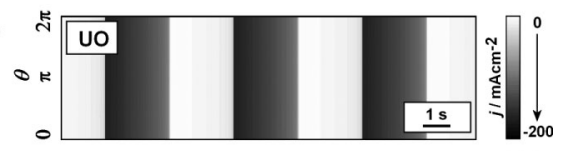

(c)

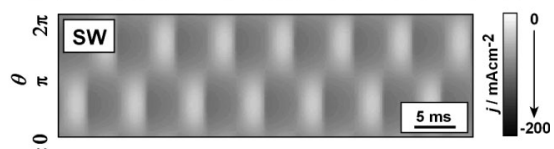

(d)

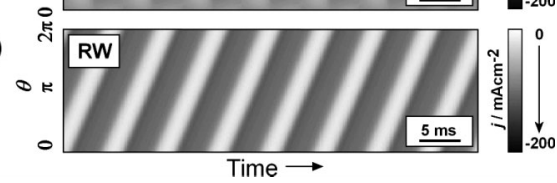

Fig. 4. (a) Schematic of an equivalent circuit for an electrochemical cell. (b)-(d) Spatiotemporal plots of the local current density calculated from equations (4) and (5). Black denotes high (active) and white low (passive) current density, respectively. Critical parameters; (b) $U=-0.170 \mathrm{~V}, s=0.00$, (c) $U=-0.136 \mathrm{~V}, s=0.69$, and (d) $U=-0.140 \mathrm{~V}$, $s=0.69$.

$$
\frac{\delta}{2} \frac{d C}{d t}=\frac{D_{\mathrm{C}}}{\delta}\left(C_{\mathrm{b}}-C\right)-\frac{I_{\mathrm{H}_{2} \mathrm{O}_{2}}}{n F}
$$

(2) 式はキルヒホッフ則であり, 系を流れる電流（右 辺) は電気二重層の充放電電流 (左辺第 1 項) とファラ デー電流（左辺第 2 項）から成ることを意味している。 ここで $\mathrm{A}$ は電極面積, $C_{\mathrm{DL}}$ は電気二重層容量, $U$ は外部 設定電位, $R_{\Omega}$ は溶液抵抗である。 $I_{\mathrm{F}}$ はファラデー電流 であり, $E$ と $C$, そして upd-H 被覆率 $\theta$ の関数である。 一方，（3）式は $C$ がバルクからの拡散による供給（右 辺第 1 項）と反応による消費（右辺第 2 項）により決ま ることを意味しており， $\delta$ は拡散層の厚さ， $C_{\mathrm{b}}$ は $\mathrm{H}_{2} \mathrm{O}_{2}$ バルク濃度, $n$ は電子数, $F$ はファラデー定数である。

電極表面上での 2 次元的な時空間パターンを記述する ためには, これに空間的なカップリング効果, すなわち PLC 効果と NGC 効果を考虑する必要がある。

$$
\begin{aligned}
& \frac{\partial E}{\partial t}=\frac{-I_{\mathrm{F}}(E, C, \theta)}{A C_{\mathrm{DL}}}+\frac{U-E}{A C_{\mathrm{DL}} R_{\Omega}}+s \frac{U-(E)}{A C_{\mathrm{DL}} R_{\Omega}}+D_{\mathrm{E}} \frac{\partial^{2} E}{\partial x^{2}} \\
& \frac{\partial C}{\partial t}=\frac{2 D_{\mathrm{C}}}{\delta^{2}}\left(C_{\mathrm{b}}-C\right)-\frac{2 I_{\mathrm{H}_{2} \mathrm{O}_{2}}}{\delta \mathrm{n} F}+D_{\mathrm{C}} \frac{\partial^{2} \mathrm{C}}{\partial x^{2}}
\end{aligned}
$$

（4）式第3 項は NGC 効果を表している。溶液中を流 れる電流の平均值 $\left(\frac{U-(E)}{R_{\Omega}},(E)\right.$ は $E$ の平均を意味する $)$ と RE-CE 間の距離 $s$ に依存して NGC 効果が寄与してく る。第 4 項はラプラス方程式をWE の周りで 2 次まで テーラー展開してPLC 効果を拡散的に記述したもので あり， $D_{\mathrm{E}}$ は電位の仮想的な拡散係数である。Fig. 4 (b)〜 (d) に上記モデルに基づき得られたシミュレーシ ヨン結果を示す。(1) $s$ の值の増加とともに空間対称性が 破れ RW P SW が現れるようになる，(2) SW は RW よ りも正の領域で現れる，など実験結果とよく合致した結 果がこの簡単なモデルにより得られている。(4) 式お よび（5）式で記述されるモデルにおいて特筆すべきこ とは, これらが (1) 式と同じ反応拡散方程式であるこ とである。先に述べたように，このモデルは実験結果と よく整合し，このことは電気化学反応系における時空間 パターン形成が他の一般的な反応拡散パターンと同じ枠 組みで議論できることを明確に示している。

では何故, REの位置 $(s$ の值) に依存して反応の空 間対称性が破れて SW や RW が現れるようになるの か? 残念ながら，この問いには上述したシミュレーショ ンでは答えることはできず，（4）および（5）式の解 の分岐挙動を詳細に調べる必要がある。これは大変複雑 な数理解析であり, 本誌の領域を大きく逸脱するので詳 述は避けるが, ここではそのエッセンスを簡単に紹介し たい。 

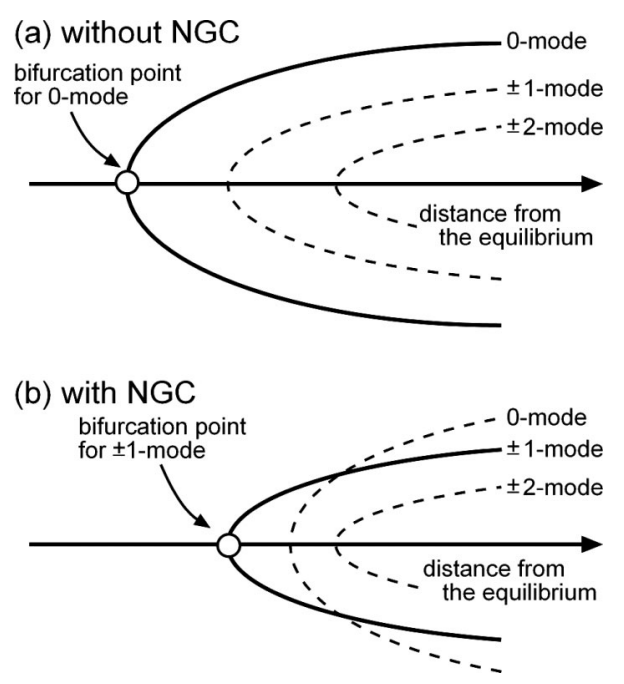

Fig. 5. Schematic illustrations for explaining the mechanism of the earlier destabilization of \pm 1 -modes by the NGC effect.

一般に, 2 変数で記述される反応拡散系では, 時間対 称性の破れ（振動現象）と空間対称性の破れ（パターン 形成）は共存できない。言い換えると, SW PW のよ うな時間振動する空間パターンは決して現れない。これ は空間波数が 0 のモード（HW のような空間一様なモー ド）が \pm 1 などの高次モード（SW や RW のような空間 非一様なモード）よりも常に先に不安定化（分岐）する ためである（Fig.5（a）。拡散現象は系を一様にするよ うに働くから（(4) 式第 4 項), $s=0$ で（4）式第 3 項が消えているような状況では, 空間非一様な高次モー ドが 0 モードよりも現れにくいのは当然である。

一方， $s$ が值を持つ場合には (4) 式第 3 項が関与し てくる。ところが，前に述べたように NGC 効果は空間 平均 $(E)$ に依存し, また空間波数 $m$ 次のモードは $\sin \frac{2 \pi m x}{L}+\cos \frac{2 \pi m x}{L}$ で表されるため, $m$ 次のモードに 対しては常に $(E)=0$ が成り立ち, 実際には NGC 効果 は高次モードには効いてこない。言い換えると, NGC 効果は 0 次モードだけを特異的に後退させ, その結果と して SW RW のような \pm 1 モードが先に現れてくる ようになる（Fig. 5（b））。このように, 通常は不安定で 隠されている系の時空間構造にアクセスできるのが電気 化学系における時空間パターン形成の大きな特徴の一つ である。

\section{5.さいごに}

以上, 筆者らが研究を進めている電気化学反応系にお
ける時空間パターン形成について最近の成果を中心に紹 介した。本稿では, $\mathrm{Pt}$ 電極表面上での $\mathrm{H}_{2} \mathrm{O}_{2}$ 還元反応を 例として取り上げたが，（4）および（５）式で記述さ れるモデルは系を問わない一般的なものである。系の個 性はこれらの式中のファラデー電流 $I_{\mathrm{F}}$ の項に反映され る。当然のことながら, upd-H のような電極反応阻害吸 着種の被覆率の電位依存性や, その電極反応活性種との 相互作用などが変化すると， I I 項の構造も大きく変わ り，このことがパターン形成などのマクロな挙動にまで 影響するようになる。

このように, 電極反応系における時空間パターン形成 に関しては, 実験から数值シミュレーション, そして数 理分岐解析と系を全体・多角的に捉える大きな枠組みが でき上がってきたと言える。しかし，一方で，分子レべ ルでの表面反応ダイナミクスの非線形性がどのように巨 視的なパターン形成に影響を及ぼすのか, また逆に, 巨 視的なパターンがどのように分子レベルでの表面反応に フィードバックしてくるのか, という最も興味深い点は まだ十分に明らかにされていない。今後, 本稿で紹介し たアプローチを軸に, 非線形なものを非線形なままに捉 え, ミクロとマクロを滑らかに繋ぐ理論の構築が期待さ れる。

\section{謝辞}

ここで紹介した研究は大阪大学大学院基礎工学研究科 数理モデル研究室・小川知之准教授, および大学院生諸 氏との共同研究によるものである。また, 本研究を通し て大阪大学・中戸義禮名誉教授 (現関西学院大学, 大阪 大学産業技術研究所客員教授）には種々のご助言を戴き ました。ここに記して感謝します。

\section{文献}

1) H.H. Rotermund, W. Engel, M. Kordesch and G. Ertl : Nature 343, 355 (1990).

2) J.L. Hudson and T.T. Tsotsis : Chem. Eng. Sci. 49, 1493 (1994).

3) K. Krischer: "Advances in Electrochemical Science and Engineering”, ed. by R.C. Alkire and D.M. Kolb (WileyVCH, Weinheim, 2003) p. 89.

4) Y. Mukouyama, S. Nakanishi and Y. Nakato: Bull. Chem. Soc. Jpn. 72, 2573 (1999).

5) P. Strasser, M. Lübke, C. Eickes and M. Eiswirth : J. Electroanal. Chem. 462, 19 (1999).

6) O. Lev, M. Sheintuch, L.M. Piseman and C. Yarnitzky : Nature 336, 458 (1988).

7) J. Christoph and M. Eiswirth : Chaos 12, 215 (2002). 